\title{
STANDARISASI EKSTRAK AIR DAUN JATI BELANDA DAN TEH HIJAU
}

\author{
Ahmad Najib, Abd. Malik, Aktsar Roskiana Ahmad, Virsa Handayani, \\ Rezki Amriati Syarif, Risda Waris \\ Fakultas Farmasi, Universitas Muslim Indonesia \\ aktsar.roskiana@umi.ac.id
}

\begin{abstract}
ABSTRAK
Teh hijau memiliki nama spesies Camellia sinensis (L.) Kuntze, family Theaceae dan Jati belanda (Guazuma ulmifolia Lam.) termasuk kedalam family sterculiaceae Tujuan Penelitian ini adalah melakukan standarisasi ekstrak air daun jati belanda dan ekstrak air the hijau. Ekstrak distandardisasi dengan beberapa dua parameter yaitu parameter spesifik dan parameter non spesifik. Kadar sari larut air pada jati belanda 12,88 \% dan teh hijau 40,88, sedangkan kadar sari larut etanol pada jati belanda 4, 23 \% dan pada teh hijau 4,23 \%. Hasil pengujian kandungan kimia menunjukkan pada ekstrak jati belanda mengandung saponin dan flavonoid sedangkan pada teh hijau mengandung tannin dan flavonoid. Kadar air ekstrak daun jati belanda 0,95\% dan teh hijau 2,79\%. Hasil kadar abu total jati belanda sebesar 37,61\% dan teh hijau 36,84\%. Kadar abu tidak larut asam yaitu pada jati belanda sebesar 3,54\% dan teh hijau 3,77\%. Hasil dari penetapan susut pengeringan pada ekstrak jati belanda yaitu 0,46\% dan teh hijau 0,46\%. Ekstrak jati belanda maupun teh hijau berdasarkan pengujian standarisasi meliputi parameter spesifik dan no-spesifik memenuhi standarisasi mutu bahan baku.
\end{abstract}

Keywords: The Hijau, Jati Belanda, Standarisasi, Saponn, Flavonoid

\section{PENDAHULUAN}

Obat tradisional dibuat dalam bentuk ekstrak karena tanaman obat tidak lagi praktis jika digunakan dalam bentuk bahan utuh (simplisia). Ekstrak tersebut bisa dalam bentuk ekstrak kering, ekstrak kental dan ekstrak cair yang proses pembuatannya disesuaikan dengan bahan aktif yang dikandung serta maksud penggunaannya (Anam et al., 2013).

Pengembangan obat tradisional diusahakan agar dapat sejalan dengan pengobatan modern. Berbagai penelitian dan pengembangan yang memanfaatkan kemajuan tekhnologi juga dilakukan sebagai upaya peningkatan mutu dan keamanan produk yang diharapkan dapat lebih meningkatkan kepercayaan terhadap manfaat obat tradisional tersebut. Pengembangan obat tradisional juga didukung oleh Peraturan Menteri Kesehatan Republik Indonesia, tentang fitofarmaka, yang berarti diperlukan adanya pengendalian mutu simplisia yang akan digunakan untuk bahan baku obat atau sediaan galenik (BPOM, 2005; Tjitrosoepomo, G., 1994).

\section{METODE PENELITIAN}

\section{A. Waktu dan Lokasi Penelitian}

Penelitian ini dilakukan di laboratorium

Farmakognosi-Fitokimia Fakultas Farmasi Universitas Muslim Indonesia pada bulan November-Februari 2016.

\section{B. Alat dan Bahan}

Alat yang digunakan adalah batang pengaduk, cawan porselin, Chamber $\left(\mathrm{Camag}^{\circledR}\right)$, gelas piala $250 \mathrm{ml}$ Pirex $\left.^{\circledR}\right)$, gelas ukur $25 \mathrm{ml}$ dan $100 \mathrm{ml}$ $\left(\right.$ Pirex $\left.^{\circledR}\right)$, desikator, kertas saring Whatman no 42, kertas saring bebas abu, krus silikat, Labu Erlenmeyer $\left(\right.$ Pire $\left.^{\circledR}\right), \quad$ pipet volume $\quad\left(\right.$ Pirex $\left.^{\circledR}\right)$, rotary vacuum evaporator (Buchi ${ }^{\circledR}$ Rotavapor R220), tabung reaksi (iwaki Pirex ${ }^{\circledR}$ ), spektrofotometri serapan atom (Aurora ${ }^{\circledR}$ ), sendok tanduk, tanur (Furnace ${ }^{\circledR}$ ), dan timbangan analitik $\left(\operatorname{Kern}^{\circledR}\right)$.

Bahan-bahan yang digunakan adalah aquadest, aluminium foil, kertas saring, etanol $70 \%$, asam nitrat (p.a), asam sulfat, larutan baku timbale (II) nitrat, larutan baku cadmium, dan sampel daun jati belanda dan teh hijau

\section{Prosedur Penelitian}

1. Penyiapan alat dan bahan

Alat dan bahan disiapkan sesuai dengan kebutuhan penelitian yang akan dilaksanakan.

\section{Pengambilan dan Pengolahan Sampel}

Sampel daun jati belanda dan teh hijau yang telah diperoleh dibersihkan dari kotoran yang melekat dengan cara dicuci dengan air mengalir kemudian dikeringkan dengan cara diangin-anginkan pada tempat yang tidak terkena sinar matahari langsung kemudian dipotong kecil-kecil, diserbukan dan siap untuk diekstraksi.

\section{Metode ekstraksi}

Ditimbang 500 gr daun jati belanda dan teh hijau, kemudian dimasukan kedalam bejana maserasi. Dituang secara perlahan pelarut etanol kedalam 
bejana maserasi yang berisi serbuk daun jati belanda dan teh hijau. Kemudian biarkan cairan penyari merendam serbuk simplisia selama 3 hari sesekali dilakukan pengadukan, dilakukan remaserasi hingga bening. Selanjutnya disari kedalam wadah baru sehingga diperoleh ekstrak cair. Hasil penyarian dari ekstrak diuapkan dengan menggunakan rotavapor dibawah titik didih hingga diperoleh ekstrak kental (Ditjen POM, 2000).

\section{Penetapan parameter spesifik a. Parameter identitas ekstrak}

Parameter identitas ekstrak dilakukan dengan tujuan memberikan identitas objektif dari nama tumbuhan. Deskripsi tata nama mencakup nama ekstrak, nama latin tumbuhan, bagian tumbuhan yang digunakan serta nama Indonesia tumbuhan (Depkes RI, 2000).

\section{b. Uji organoleptik}

Uji organoleptik merupakan pengenalan awal yang sederhana seobjektif mungkin. Uji organoleptik dilakukan dengan pengamatan terhadap bentuk, warna, bau, dan rasa (Depkes RI, 2000).

\section{c. Uji senyawa yang larut dalam air}

Sejumlah 5 gram ekstrak dimaserasi selama 24 jam dengan $100 \mathrm{ml}$ air-kloroform menggunakan labu bersumbat sambil dikocok selama 6 jam pertama dan kemudian dibiarkan selama 18 jam, kemudian disaring. Uapkan $20 \mathrm{ml}$ filtrate hingga kering dalam cawan dangkal berdasar rata yang telah ditara. Residu dipanaskan pada suhu $105^{\circ} \mathrm{C}$ hingga bobot tetap. Hitung kadar dalam persen senyawa yang larut dalam air terhadap berat ekstrak awal (Depkes RI, 2000).

\section{d. Kadar senyawa yang larut dalam etanol}

Sejumlah 5 gram ekstrak dimaserasi selama 24 jam dengan $100 \mathrm{ml}$ etanol (95\%) menggunakan labu bersumbat sambil berkali-kali dikocok selama 6 jam pertama dan kemudian dibiarkan selama 18 jam. Disaring cepat dengan menghindari penguapan etanol, kemudian diuapkan $20 \mathrm{ml}$ filtrat hingga kering dalam cawan penguap yang telah ditera, residu dipanaskan pada suhu $105^{\circ} \mathrm{C}$ hingga bobot tetap. Dihitung kadar dalam persen senyawa yang larut dalam etanol terhadap berat ekstrak awal (Depkes RI, 2000).

\section{e. Uji kandungan kimia ekstrak Profil KLT ekstrak}

a. Uji terpenoid

Fase gerak dibuat campuran heksanetilasetat (1:1) dimasukkan ke dalam chamber dan dibiarkan sampai jenuh. Pada plat KLT GF GF $_{25}$ ditotolkan kira-kira $5 \mu \mathrm{l}$ sari heksan dan dimasukkan pada chamber, dielusi sampai tanda, diambil dan dibiarkan sampai kering. Ekstrak mengandung terpenoid bebas bila dilihat dibawah sinar UV $365 \mathrm{~nm}$ berfluoresensi hijau / berwarna merah ungu atau biru dengan pereaksi asam sulfat pekat $10 \%$ dalam methanol (sthahl Egol, 1969).

\section{b. Uji Alkaloid}

Dibuat fase gerak etilasetat - metanol - air (100:13,5:10) dimasukkan dalam chamber, dibiarkan sampai jenuh. Pada plat KLT GF 254 p ditotolkan kirakira $5 \mu$ masing - masing sari etil asetat, air, masukkan dalam chamber, dielusi sampai tanda, diambil dan dibiarkan sampai kering. Ekstrak mengandung alkaloid bebas bila dilihat dibawah sinar UV $365 \mathrm{~nm}$ berfluoresensi hijau / berwarna jingga dengan pereaksi Dragendorf (sthahl Egol, 1969).

\section{c. Uji Flavonoid}

Dibuat fase gerak kloroform - etilasetat (6 : 4) dimasukkan dalam chamber, dibiarkan sampai jenuh. Pada plat KLT GF 254 p ditotolkan kira-kira $5 \mu \mathrm{l}$ masing - masing sari etil asetat, air, lalu dimasukan dalam chamber, dielusi sampai tanda. Ekstrak mengandung flavonoid bebas bila dilihat dibawah sinar UV $365 \mathrm{~nm}$ berfluoresensi hijau / berwarna biru atau kuning dengan pereaksi sitro borat (sthahl Egol, 1969).

\section{Penetapan parameter non spesifik \\ a. Penetapan susut pengeringan}

Ekstrak ditimbang secara seksama sebanyak $1 \mathrm{~g}$ sampai $2 \mathrm{~g}$ dan dimasukan kedalam botol timbang dangkal tertutup yang sebelumnya telah dipanaskan pada suhu $105^{\circ} \mathrm{C}$ selama 30 menitdan telah ditara. Sebelum ditimbang, ekstrak diratakan dalam botol timbang, dengan menggoyangkan botol hingga merupakan lapisan setebal kurang $5 \mathrm{~mm}$ sampai 10 $\mathrm{mm}$, kemudian dimasuka kedalam ruang pengering. Dibuka tutupnya, keringkan pada suhu $105^{\circ} \mathrm{C}$ hingga botol tetap. Sebelum setiap pengeringan, biarkan botol dalam keadaan tertutup mendingin dalam eksikator hingga suhu kamar. Kemudian keringkan kembali pada suhu penetapan hingga bobot tetap (Depkes RI, 2000).

\section{b. Kadar air Metode gravimetri}

Masukan lebih kurang 1 gram ekstrak dan ditimbang seksama dalam wadah yang telah ditara. Keringkan pada suhu $105^{\circ} \mathrm{C}$ selama 5 jam dan ditimbang. Lanjutkan pengeringan dan timbang pada jarak 1 jam sampai perbedaan antara 2 penimbangan berturut-turut tidak lebih dari 0,25\% (Depkes RI, 2000). 


\section{c. Kadar abu}

\section{Penetapan kadar abu total}

Lebih kurang 2 gram sampai 3 gram ekstrak yang telah digerus dan ditimbang seksama, dimasukan kedalam krus silikat yang telah dipijarkan dan ditara, ratakan. Pijarkan perlahan-lahan hingga arang habis, dinginkan, timbang. Jika cara ini arang tidak dapat dihilangkan, tambahkan air panas. Saring melalui kertas saring bebas abu. Pijarkan sisa kertas dan kertas saring dalam krus yang sama. Masukan filtrat kedalam krus. Uapakan, pijarkan ingga bobot tetap. Timbang, hitung kadar abu terhada bahan yang telah dikeringkan diudara (Depkes RI, 2000).

\section{Penetapn kadar abu yang tidak larut dalam asam}

Abu yang diperoleh dari penetapan kadar abu, didihkan dengan $25 \mathrm{ml}$ asam sulfat encer $\mathrm{P}$ selama 5 menit, bagian yang tidak larut asam dikumpulkan, disaring melalui kertas saring bebas abu, dicuci dengan air panas, pijarkan hingga bobot tetap, timbang. Hitung kadar kadar abu yang tidak larut dalam asam terhadap bahan yang telah dikeringkan di udara (Depkes RI, 2000).

\section{Cemaran logam berat}

\section{Spektrofotometer AAs (Pb dan $\mathbf{C d})$}

a. Pembuatan kurva baku $\mathrm{Pd}$ dan $\mathrm{Cd}$

Dari larutan baku $\mathrm{Pb}\left(\mathrm{NO}_{3}\right)_{2}$ dipipet $5 \mathrm{ml}$ kemudian dicukupkan volumenya hingga $50 \mathrm{ml}$ dengan $\mathrm{HNO}_{3} 2 \%$ dari larutan ini dipipet $1 \mathrm{ml}, 2 \mathrm{ml}, 3$ $\mathrm{ml}, 4 \mathrm{ml}$, dan $5 \mathrm{ml}$. kemudian dimasukan kedalam labu tentukur $50 \mathrm{ml}$ dan dicukupkan volumenya hingga batas tanda. Diperoleh larutan baku dengan konsentrasi 2 bpj, 4 bpj, 6 bpj, 8 bpj dan 10 bpj.

Dari larutan baku Cd $\left(\mathrm{NO}_{3}\right)_{2} 1000$ bpj dipipet $5 \mathrm{ml}$ kemudian dicukupkan volumenya hingga $50 \mathrm{ml}$ dengan $\mathrm{HNO}_{3} 2 \%$ (100 bpj). Dari larutan ini dipipet 1 $\mathrm{ml}, 2 \mathrm{ml}, 3 \mathrm{ml}, 4 \mathrm{ml}$ dan $5 \mathrm{ml}$. kemudian dimasukan kedalam labu tentukur $100 \mathrm{ml}$ dan dicukupkan volumenya hingga batas tanda. Diperoleh larutan baku dengan konsentrasi 0,1 bpj, 0,2 bpj, 0,3 bpj, 0,4 bpj dan 0,5 bpj.

\section{b. Larutan uji}

Ditimbang dengan teliti $5 \mathrm{~g}$ sampel kemudian dimasukan dalam beker gelas, ditambahkan $5 \mathrm{ml} \mathrm{HNO}_{3}$ p.a dan $1 \mathrm{ml} \mathrm{HClO}_{4}$ p.a lalu didestruksi pada suhu $200^{\circ} \mathrm{C}$ sampai diperoleh larutan jernih, didinginkan dan disaring menggunakan kertas whatman No 40-41. Dimasukan dalam labu ukur 50 $\mathrm{ml}$, dan cukupkan volumenya dengan aquadest.

c. Pengukuran kadar logam

Kadar logam pb diukur menggunakan spektrofotometer serapan atom pada panjang gelombang $217 \mathrm{~nm}$, sedangkan kadar cadmium diukur pada panjang gelombang $288,8 \mathrm{~nm}$.

\section{Bobot jenis}

Gunakan piknometer bersih, kering dan telah dikalibrasi dengan menetapkan bobot piknometer dan bobot air yang baru didihkan pada suhu $25^{\circ} \mathrm{C}$. Atur hingga suhu ekstrak cair lebih kurang $20^{\circ} \mathrm{C}$, masukkan ke dalam piknometer. Atur suhu piknometer yang telah diisi hingga suhu $25^{\circ} \mathrm{C}$, buang kelebihan ekstrak cair dan ditimbang. Kurangkan bobot piknometer kosong dari bobot piknometer yang telah diisi. Bobot jenis ekstrak dengan bobot air, dalam piknometer pada suhu $25^{\circ} \mathrm{C}$.

\section{HASIL DAN PEMBAHASAN}

Standarisasi dalam kefarmasian tidak lain adalah serangkaian parameter, prosedur dan cara pengukuran yang hasilnya merupakan unsur-unsur terkait paradigma kefarmasian, mutu dalam artian memenuhi syarat standar (kimia, biologi dan farmasi), termasuk jaminan batas-batas stabilitas sebagai produk kefarmasian umumnya. Dengan kata lain, pengertian standarisasi juga berarti proses menjamin bahwa produk akhir obat (obat, ekstrak atau produk ekstrak) mempunyai nilai parameter tertentu yang konstan dan ditetapkan terlebih dahulu. Terdapat dua faktor yang mempengaruhi mutu ekstrak yaitu faktor biologi dari bahan asal tumbuhan obat dan faktor kandungan kimia bahan obat tersebut (Depkes RI 2000).

Standardisasi adalah proses penetapan sifat berdasarkan parameter-parameter tertentu untuk mencapai derajat kualitas yang sama. Ekstrak distandardisasi dengan beberapa dua parameter yaitu parameter spesifik dan parameter non spesifik (Handa et al., 2008). Parameter spesifik meliputi identitas, organoleptic, senyawa kimia larut air dan etanol, kandungan kimia. Sedangkan parameter non spesifik meliputi susut pengeringan, kadar air, kadar abu, cemaran logam dan bobot jenis.

Identitas ekstrak sangat penting dalam pengujian pendahuluan sebagai pengenalan awal dan bagain tanaman yang digunakan. Penelitian ini sesuai dengan hasil identifikasi tanaman menggunakan teh hijau Camellia sinensis (L.) Kuntze, family Theaceae dan daun jati belanda Guazuma ulmifolia Lam. family sterculiaceae, pada penelitian ini bagian tanaman yang digunakan adalah daun (folium).

Uji orngoleptik pada daun jati belanda dan teh hijau merupakan ekstrak kering bewarna hijau kekuningan serta rasa yang sepat dikarenakan kedua tanaman ini kaya akan senyawa tannin yang memberikan rasa sepat pada indera pengecapan.

Kadar sari larut air pada jati belanda $12,88 \%$ dan teh hijau 40,89\%, sedangkan kadar sari larut 
etanol pada jati belanda $12,05 \%$, dan pada teh hijau $4,23 \%$. Hasil pada pengujian kadar sari larut air memenuhi persyaratan mutu karena memiliki kadar lebih besar dari 6\% (>6\%). Hasil yang berbeda ditunjukkan pada pengujian kadar sari larut etanol hal ini karena ekstrak yang digunakan adalah ekstrak air.

Pada proses ekstraksi metode yang diguankan adalah metode maerasi modifikasi microwave, metode ini membutuhkan waktu yang lebih singkat dan efisien melihat pelarit yang diguakan adalah pelarut air sehingga harus dengan proses ektraksi yang cepat. Hasil pengujian kandungan kimia menunjukkan pada ekstrak jati belanda mengandung saponin dan flavonoid sedangkan pada teh hijau mengandung tannin dan flavonoid. Pelarut air pada proses ekstraksi lebih spesifik ditargetkan pada senyawa-senyawa polar seperti tannin, saponin dan flavonoid.

Tabel 1. Hasil standardisasi parameter spesifik JB

\begin{tabular}{lll}
\hline No & Pengujian & Hasil \\
\hline 1 & Identitas ekstrak & $\begin{array}{l}\text { Nama latin : } \\
\text { Bagian tanaman : } \\
\text { daun }\end{array}$ \\
2 & Organoleptik & $\begin{array}{l}\text { Kental, rasa sepat, } \\
\text { warna hijau } \\
12,88\end{array}$ \\
3 & $\begin{array}{l}\text { Kadar sari larut } \\
\text { air }\end{array}$ & $\begin{array}{l}\text { Kadar sari larut } \\
\text { etanol } \\
5\end{array}$ \\
& $\begin{array}{l}\text { Kandungan } \\
\text { kimia }\end{array}$ & $\begin{array}{l}\text { Saponin, } \\
\text { flavonoid }\end{array}$ \\
\hline
\end{tabular}

Tabel 2. Hasil standardisasi parameter spesifik TH

\begin{tabular}{lll}
\hline No & Pengujian & Hasil \\
\hline 1 & Identitas ekstrak & $\begin{array}{l}\text { Nama latin : } \\
\text { Bagian tanaman : } \\
\text { daun }\end{array}$ \\
& & $\begin{array}{l}\text { Kental, rasa sepat, } \\
\text { warna hijau }\end{array}$ \\
2 & Organoleptik & 40,89 \\
3 & Kadar sari larut air & 4,23 \\
4 & Kadar sari larut & \\
& etanol & Tanin, saponin \\
\hline
\end{tabular}

Penentuan kadar air pada ekstrak bertujuan untuk memberi batasan minimal atau rentang tentang besarnya kandungan air dalam bahan (ekstrak,) makin tinggi kadar air, makin mudah untuk ditumbuhi jamur, kapang sehingga dapat menurunkan aktivitas biologi ekstrak dalam masa penyimpanan. Kadar air tergantung pada waktu pengeringan simplisia, makin kering makin kecil kadar airnya. Prinsipnya yaitu menguapkan air yang ada pada sampel atau dengan cara pemanasan pada suhu $105^{\circ} \mathrm{C}$ selama 5 jam
(Mutiatikum 2015, h. 5). Menurut FHI 2000, umumnya kandungan kadar air yang dipersyaratkan adalah kurang dari 10\%. Sehingga dapat disimpulkan bahwa kadar air ekstrak daun jati belanda $0,96 \%$ dan teh hijau 2,80\% memenuhi standar mutu.

Penentuan kadar abu diukur dengan memasukkan ekstrak ke dalam tanur dengan temperatur $450^{\circ} \mathrm{C}$ sampai terbentuk abu. Kadar abu ditentukan dalam persenterhadap bobot awal. Kadar abu total juga dapat digunakan sebagai landasan untuk mengetahui kandungan mineral internal dan eksternal yang berasal dari proses awal sampai akhir pembuatan ekstrak. Hasil kadar abu total jati belanda sebesar $37,62 \%$ dan teh hijau 36,84\%. Kadar abu tidak larut asam yaitu pada jati belanda sebesar $2,55 \%$ dan teh hijau 3,54\%.

Penetapan susut pengeringan pada ekstrak merupakan salah satu persyaratan yang harus dipenuhi dalam standardisasi tumbuhan yang berkhasiat obat dengan tujuan dapat memberikan batas maksimal (rentang) tentang besarnya senyawa yang hilang pada proses pengeringan. Pada uji susut pengeringan ini dilakukan pengukuran sisa zat setelah pengeringan pada suhu $105^{\circ} \mathrm{C}$ selama 30 menit. Pada suhu $105^{\circ} \mathrm{C}$ air akan menguap dan senyawa-senyawa yang mempunyai titik didih yang lebih rendah dari air akan ikut menguap juga (Depkes RI 2000). Adapun hasil dari penetapan susut pengeringan pada ekstrak jati belanda yaitu 4,04\% dan teh hijau 0,47\%. Untuk parameter susut pengeringan tidak ada syarat atau rentang nilai yang diperbolehkan.

Tabel 3. Hasil standardisasi parameter non spesifik JB

\begin{tabular}{lll}
\hline No & Nama & Kandungan $(\%)$ \\
\hline 1 & Kadar air & 0,96 \\
2 & Kadar abu total & 37,62 \\
3 & Kadar abu tidak & 2,55 \\
& $\begin{array}{l}\text { larut asam } \\
4\end{array}$ & $\begin{array}{l}\text { Susut } \\
\text { pengeringan }\end{array}$ \\
\end{tabular}

Tabel 4. Hasil standardisasi parameter non spesifik TH

\begin{tabular}{lll}
\hline No & Nama & Kandungan $(\%)$ \\
\hline 1 & Kadar air & 2,80 \\
2 & Kadar abu total & 36,84 \\
3 & Kadar abu tidak & 3,54 \\
& $\begin{array}{l}\text { larut asam } \\
4\end{array}$ & $\begin{array}{l}\text { Susut } \\
\text { pengeringan }\end{array}$ \\
\hline
\end{tabular}

\section{KESIMPULAN}

Ekstrak jati belanda maupun teh hijau berdasarkan pengujian standarisasi meliputi parameter spesifik dan no-spesifik memenuhi standarisasi mutu bahan baku. 


\section{UCAPAN TERIMA KASIH}

Ucapan terima kasih tim peneliti ucapkan kepada Fakultas Farmasi UMI yang telah memfasilitasi penelitian ini dan Lembaga Penelitian dan Pengembangan UMI yang telah mendanai penelitian ini.

\section{DAFTAR PUSTAKA}

Anam, S., Yusran, M., Trisakti, A., Ibrahim, N., Khumaidi, A., Ramadanil, dan Zubair, M.S, 2013. Standarisasi Ekstrak Etil Asetat Kayu Sanrego (Lunasia amara Blanco), Jurnal of Natural Science, Vol2. (3):1-8

BPOM RI., 2000. Parameter Standar Umum Ekstrak Tumbuhan Obat. Jakarta: Departemen Kesehatan Republik Indonesia.

BPOM RI., 2004. Monografi Ekstrak Tumbuhan Indonesia, vol 1. Jakarta: Badan pengawasan Obat dan Makanan Republik Indonesia.

Direktorat Jenderal Pengawasan Obat dan Makanan, 1986. Sediaan Galenik. Jakarta: Departemen Kesehatan Republic Indonesia.

Ebdon, L., Evans, E H. Fisher, A., dan Hill, S. J. 1998. An introduction toanalitical atomic spectrometry. Chichester. Jhon Wiley \& Sons.

Gandjar, I.G., dan Rohman, Abdul, 2007. Kimia Farmasi Analisis. Penerbit Pustaka Pelajar. Yogyakarta. 298-318

Heyne, K., 1987, Tumbuhan Berguna Indonesia Jilid II, Departemen Kehutanan, Terjemahan Badan Litbang Kehutanan: Jakarta

Hariyati, S., 2005, Standarisasi Ekstrak Tumbuhan Obat Indonesia, Salah Satu Tahapan Penting dalam Pengembangan Obat Asli Indonesia, InfoPOM, 6(4), 1-5

Info POM, 2005. Standarisasi Ekstrak Tumbuhan Obat Indonesia, Salah Satu Tahapan Penting Dalam Pengembangan Obat Asli Indonesia. Badan POM RI, Vol.6, No. 4, 1-5.

Khoirani, N., 2013, Karakterisasi Simplisia dan Standarisasi Ekstrak Etanol Herba Kemangi (Ocimum americanum L) Skripsi, Jurusan Farmasi UIN Syarif Hidayatullah, Jakarta

Perkin-Elmer Corporation. 1996. Analytical methods for atomic absorption spectroscopy. USA: Perkin.Elmer

Puro, I., 2012, Kajian Aktivitas Antibakteri Daun jati belanda dan teh hijau (Roxb.) Wedd.) Dan Daun Benalu Cengkeh, Skripsi, Fakultas Teknologi Pertanian Institut Pertanian, Bogor.

Putri, E., Anggraeni, Y., Khairina., 2012. Standarisasi Ekstrak Etanol daun Pegagan (Centella asitica L Uraban) Yang Berasal Dari Malang dan Penetapan Kadar Asiatikosida, Skripsi, Jurusan Farmasi UIN Syarif Hidayatullah, Jakarta

Rustian., 1993. Pemeriksaan Jumlah Total Cemaran Bakteri dan Kapang Serta Identifikasi Aspergillus Flavus Pada Sediaan Jamu Bubuk di Beberapa Tempat Penjualan di Kotamadya Padang, Skripsi, S.Farm., Fakultas MIPA, UNAND, Padang.

Sthahl E., 1969. Thin Layer Chrmatography, Heidelberg, New York

Saefudin, A., Rahayu, Teruna, 2011, Standarisasi Bahan Obat Alam. Graha Ilmu: Yogyakarta

Tjitrosoepomo, G., 1994, Taksonomi Tumbuhan Obat-obatan. Gadjah Mada University Press: Yogyakarta. 421-423

Vandecasteele, C., Block, C. B., 1993. Modern Methods For Trace Element Determination, John Wiley and Sons, New York.

Welz, B., dan Michael, S. 2005. Atomic Absoption spectrometry Ed. Ke-3. New York

World Health Organization, 2009. Medicinal plants in Papua New Guinea. Manila: World Health Organization, regional office for the Western Pacific. 